\title{
Interruption of machine milking in dairy cows: effects on intramammary pressure and milking characteristics
}

\author{
By HANS-ULRICH PFEILSTICKER, RUPERT M. BRUCKMAIER* \\ AND JÜRG W. BLUM \\ Institut für Tierzucht der Universität Bern, CH-3012 Bern, Schweiz
}

(Received 8 December 1994 and accepted for publication 10 April 1995)

\begin{abstract}
Summary. Experiments were designed to test the hypothesis that milk ejection rate decreases during milking, thereby causing insufficient refill of the cistern and decreasing milk flow rate towards the end of milking. In a first series of experiments machine milking of the left front quarters of 11 cows was interrupted for 2 min after removal of 25,50 or $75 \%$ of expected total milk yield, while milking was continued in the other three quarters. Milk flow was recorded during machine-on times. Intramammary pressure (IMP) was recorded during premilking teat stimulation and during interruption of milking. IMP during interruption of milking decreased with decreasing amounts of milk remaining in the udder. The IMP did not change during these interruptions when they occurred after 25 and $50 \%$ of expected total milk yield was removed. Thus, the ejection rate could keep up with the milk flow or removal rate. However, IMP increased during interruption of milking following removal of $75 \%$ of total yield, although significantly so only in cows with a high milk flow rate. Obviously, more milk was removed than was transported to the cisternal cavity. It is likely that a reduced ejection rate caused the decreased milk flow rate. In a second series of experiments the pulsation ratio of the milking machine was changed from the usual 70:30 to 50:50 with the aim of reducing the milk flow rate and thus adapting to the ejection rate at the end of milking. The changed pulsation ratio caused a reduced peak flow rate and a prolonged high milk flow period, whereas the main flow rate did not change significantly.
\end{abstract}

The main fraction of milk stored in the mammary gland, the alveolar milk, is fixed by adhesive and capillary forces and must be actively shifted into the cisternal cavity by the milk ejection reflex to become available for removal. Premilking teat stimulation causes enhanced oxy tocin release and increased intramammary pressure (IMP) within the cistern up to a physiological maximum (Gorewit, 1979; Mayer et al. 1991; Bruckmaier et al. 1994). Oxytocin release occurs not only at the start, but continues throughout the whole milking (Mayer et al. 1984; Schams et al. 1984). However, although maximal IMP is reached, the alveolar milk is not completely ejected during prestimulation and early milking. Alveolar milk ejection lasts throughout the entire milking and continuously elevated concentrations of oxytocin are necessary for continuous and complete milk removal (Bruckmaier et al. 1994). It seems therefore possible that the milk flow rate during machine milking is limited not only by anatomical characteristics of cisterns and teats, and smooth muscle tone in

* For correspondence. 
the teat and around the cistern and large ducts (Andreae, 1958; Williams \& Mein, 1987), but also by the rate of alveolar milk transfer into the cisternal cavity during milking.

The aim of this work was to test the hypothesis that milk ejection rate decreases during milking, resulting in an insufficiently rapid refilling of the cisternal cavity. If so, it was theorized that a compensatory increase of IMP would occur during interruption of milking.

In addition, the hypothesis was tested that ejection rate can more easily adapt to milk flow rate if the pulsation ratio is lowered. For this purpose, experiments were designed in which peak flow rates (PFR) were reduced, but the main flow rate was not affected.

\section{MATERIALS AND METHODS}

\section{Cows}

All experimental cows were from the herd of the Swiss Federal Research Station for Animal Production, Posieux : Simmental $\times$ Red Holstein and Swiss Braunvieh $\times$ Brown Swiss breeds with an average milk yield of $7300 \mathrm{~kg} /$ year. Cows were kept in tie stalls and fed maize silage, hay and concentrates according to their individual production levels. Experiments were performed during routine milking from 16.00 to 18.00

\section{Recording of milk flow and intramammary pressure}

Milking was performed at a vacuum level of $45 \mathrm{kPa}$ and a pulsation rate of 60 cycles/min. Milk flow was continuously recorded using a strain gauge system and a strip chart recorder as described by Schams et al. (1984). Table 1 defines the various milking traits investigated. PFR is defined as maximum milk flow lasting for at least $10 \mathrm{~s}$, and main flow rate as milk removed until stripping divided by the corresponding milking time.

IMP was measured by a strain gauge system via a cannula through the teat canal and was continuously conveyed to a strip chart recorder as described by Bruckmaier et al. (1994). The pressure was calibrated to zero at the level of the teat base.

\section{Experiment 1}

Eleven cows in weeks 11-23 of their first to fourth lactation were milked at a 65:35 pulsation ratio. Teatcups (Alfa Laval; Harmony, S-147 21 Tumba, Sweden) were connected with a quarter milking claw (Surge RX; Babson Bros \& Co., Naperville, IL 60563, USA). Milk yield and milk flow of the left front quarter were recorded separately and those of the other three quarters were measured together.

The IMP was recorded in the left front quarter. Manual stimulation was applied until IMP reached its maximum. Milking was started subsequently. After 25, 50 or $75 \%$ of the expected milk yield (as assessed on preceding evening milkings) had been collected, milking of the left front quarter was interrupted for $2 \mathrm{~min}$. During this period IMP was measured, while milking of the remaining quarters continued. After the interruption, milking was resumed and continued until the udder was emptied. Amounts of milk removed before the interruption were measured and expressed as percent of total yields (M1 $1 / 4)$, Table 2). For interruptions between 5-35, 35-65 and $65-95 \%$ of the actual milk yield, results were classified as 25,50 and $75 \%$ respectively.

In control milkings, IMP was recorded in the left front quarter before and during manual stimulation, which was applied until IMP reached a maximum. Subsequently 


\section{Table 1. Milking characteristics and intramammary pressure traits}

$\begin{array}{lll}M 1(1 / 4) & \mathrm{kg} & \text { Milk yield in the left front quarter until interruption of milking } \\ M 2(1 / 4) & \mathrm{kg} & \text { Milk yield in the left front quarter after interruption of milking } \\ M(1 / 4) & \mathrm{kg} & \text { Total milk yield in the left front quarter } \\ \text { PFR } 1(1 / 4) & \mathrm{kg} / \mathrm{min} & \text { Peak flow rate until interruption of milking (left front quarter) } \\ \mathrm{PFR} 2(1 / 4) & \mathrm{kg} / \mathrm{min} & \text { Peak flow rate after interruption of milking (left front quarter) } \\ \Delta \mathrm{PFR}(1 / 4) & \mathrm{kg} / \mathrm{min} & \text { Difference between PFR2(1/4) and PFR1(1/4) (left front quarter) } \\ M P F R(1 / 4) & \mathrm{kg} / \mathrm{min} & \text { Maximum peak flow rate in the left front quarter (either PFR } 1(1 / 4) \text { or } \\ & \mathrm{kg} & \text { PFR2 }(1 / 4)) \\ M(3 / 4) & \mathrm{kg} / \mathrm{min} & \text { Peak flow rate in three non-interrupted quarters } \\ \mathrm{PFR}(3 / 4) & \mathrm{kg} & \text { Total milk yield } \\ M(4 / 4) & \mathrm{kPa} & \text { Intramammary pressure } \\ \mathrm{IMP} & \mathrm{kPA} & \text { Baseline pressure, IMP recorded before milk ejection } \\ \mathrm{BP} & \mathrm{kPa} & \text { Ejection pressure, maximum IMP after manual teat stimulation and before } \\ \mathrm{EP} & \mathrm{kPa} & \text { Interruption pressure, IMP just after interrupting the milking } \\ \mathrm{IP} & \mathrm{kPa} & \text { IMP change until interruption of milking } \\ \mathrm{IP}-\mathrm{EP} & \mathrm{kPa} & \text { IMP change during interruption of milking } \\ \Delta \mathrm{IP} & & \end{array}$

the other three quarters were milked, while IMP recording in the left front teat continued. After milk flow of the three quarters had dropped below $150 \mathrm{~g} / \mathrm{min}$, IMP recording was stopped. Thereafter, the left front quarter was immediately milked.

\section{Experiment 2}

Nineteen animals in weeks 3-32 of their first to eighth lactation were milked at pulsation ratios of 50:50 and 70:30. A 1 min manual teat stimulation was applied before milking. Milk flow of all quarters together was recorded continuously. After milk flow had dropped below $200 \mathrm{~g} / \mathrm{min}$ the udder was emptied by machine stripping.

\section{Evaluation of results and statistical analyses}

Results are presented in text and Tables as means $\pm s E$. For statistical evaluations the SAS program package, release 6.08 (SAS, 1990), was used. Means of different classes and groups were tested for significant differences $(P<0.05)$ using the General Linear Model procedure and Student's $t$ test. Changes during the course of one trial were tested for significance $(P<0.05)$ by means of the paired $t$ test.

In Expt 1 the animals were divided into two groups: cows with low three quarter $\operatorname{PFR}(\operatorname{PFR}(3 / 4) \leqslant 3 \mathrm{~kg} / \mathrm{min})$ and cows with high three quarter $\operatorname{PFR}(\operatorname{PFR}(3 / 4)>$ $3 \mathrm{~kg} / \mathrm{min}$ ). To assign the animals to one of the two PFR groups, the mean of the four experimental milkings (control and three interrupted milkings) was calculated. Pearson's coefficients of correlation between various traits were calculated. The repeatability $\left(w=\sigma^{2}(a) /\left(\sigma^{2}(a)+\sigma^{2}(e)\right)\right)$ was computed according to Essl (1987) employing the General Linear Model procedure based on estimated values: $\mathrm{s}^{2}(a)=$ $(\operatorname{MS}(a)-\mathrm{MS}(e)) / n$ and $\mathrm{s}^{2}(e)=\mathrm{MS}(e)$ where $\sigma^{2}$ is real variance, $\mathrm{s}^{2}$ estimated variance, MS mean square, $a$ animal, $e$ error and $n$ the number of animals. The model $\mathrm{Y}=$ $\mu+a_{j}+e_{i j}$ was used.

\section{Experiment 1}

\section{RESULTS}

Milking characteristics. The milk yield of the left front quarter $(\mathrm{M}(1 / 4))$ was $25 \cdot 8 \pm 0 \cdot 9 \%$ of the total milk yield (M(4/4)) which was $9 \cdot 73 \pm 2 \cdot 84 \mathrm{~kg}$ (Table 2). Milk yields were not significantly different between the three interrupted milkings and 
Table 2. Milking characteristics $\dagger$ and intramammary pressure before, during and after interruption of milking in cows with mean three quarter peak flow rates $(P F R(3 / 4))$ below and above $3 \mathrm{~kg} / \mathrm{min}$

(Values are means $\pm s E$ )

Interruption class, $\% \ldots$ Average $\mathrm{M1}(1 / 4), \% \ldots$ Milk flow group

(PFR(3/4)), $\mathrm{kg} / \mathrm{min} \ldots$

No. of observations...

\begin{tabular}{cc}
\multicolumn{2}{c}{$\begin{array}{l}\text { (Values } \\
25 \\
285 \pm 1 \cdot 32\end{array}$} \\
\hline $\begin{array}{c}28.0 \\
4\end{array}$ & $>3 \cdot 0$ \\
7
\end{tabular}

Trait

$\mathrm{M}(1 / 4)$

$\operatorname{M1}(1 / 4)$

$\operatorname{PFR} 1(1 / 4)$

PFR2(1/4)

$\triangle \operatorname{PFR}(1 / 4)$

$$
\begin{gathered}
\text { Unit } \\
\mathrm{kg} \\
\%
\end{gathered}
$$

$$
2 \cdot 4 \pm 0.5
$$

$28 \pm 1^{a}$ $\mathrm{kg} / \mathrm{min}$ $\mathrm{kg} / \mathrm{min}$ $\mathrm{kg} / \mathrm{min}$

$0 \cdot 6 \pm 0 \cdot 1^{*}$

$2 \cdot 6 \pm 0 \cdot 3$

$0 \cdot 7 \pm 0 \cdot 1 \quad 1 \cdot 1 \pm 0 \cdot 2^{\mathrm{A}}$

$0 \cdot 1 \pm 0 \cdot 0^{\mathrm{a}}$

$0 \cdot 1 \pm 0 \cdot 1^{\mathrm{A}}$

$1 \cdot 3 \pm 0 \cdot 1$

$\begin{array}{ll}\mathrm{BP} & \mathrm{kPa} \\ \mathrm{EP} & \mathrm{kPa}\end{array}$

IP $\mathrm{kPa}$

$\begin{array}{ll}\Delta \mathrm{IP} & \mathrm{kPa} \\ \mathrm{IP}-\mathrm{EP} & \mathrm{kPa}\end{array}$

$4 \cdot 3 \pm 0 \cdot 0$

$3 \cdot 6 \pm 0 \cdot 2^{\mathrm{a}}$

$-0 \cdot 1 \pm 0 \cdot 0^{\mathrm{a}}$
$-0.7+0 \cdot 2^{\mathrm{a}}$

$1 \cdot 8 \pm 0 \cdot 5$

$4 \cdot 1 \pm 0 \cdot 8$

$3 \cdot 4 \pm 0 \cdot 5^{\mathrm{A}}$

$0 \cdot 0 \pm 0 \cdot 1^{A}$

$-0.7 \pm 0 \cdot 2^{\mathrm{a}+} \quad-0 \cdot 7 \pm 0 \cdot 3^{\mathrm{A}}$

\begin{tabular}{cc}
\multicolumn{2}{c}{50} \\
$47 \cdot 56 \pm 2 \cdot 61$ \\
\hline$\leqslant 3 \cdot 0$ & $>3 \cdot 0$ \\
5 & 7 \\
& \\
$2 \cdot 9 \pm 0 \cdot 3$ & $2 \cdot 5 \pm 0 \cdot 2$ \\
$53 \pm 3^{b}$ & $44 \pm 3^{\mathrm{B}}$ \\
$0 \cdot 9 \pm 0 \cdot 2$ & $1 \cdot 2 \pm 0 \cdot 1$ \\
$0 \cdot 9 \pm 0 \cdot 2$ & $1 \cdot 2 \pm 0 \cdot 1^{\mathrm{A}}$ \\
$0 \cdot 0 \pm 0 \cdot 0^{\mathrm{ab}}$ & $0 \cdot 0 \pm 0 \cdot 1^{\mathrm{A}}$ \\
$1 \cdot 7 \pm 0 \cdot 0$ & $1 \cdot 5 \cdot 0 \cdot 3$ \\
$4 \cdot 1 \pm 0 \cdot 1$ & $4 \cdot 3 \pm 0 \cdot 5$ \\
$2 \cdot 8 \pm 0 \cdot 1^{\mathrm{ab}}$ & $3 \cdot 2 \pm 0 \cdot 4^{\mathrm{A}}$ \\
$0 \cdot 0 \pm 0 \cdot 1^{\mathrm{a}}$ & $-0 \cdot 1 \pm 0 \cdot 1^{\mathrm{A}}$ \\
$-1 \cdot 3 \pm 0 \cdot 1^{\mathrm{ab}+}$ & $-1 \cdot 1 \pm 0 \cdot 2^{\mathrm{A}+}$
\end{tabular}

\begin{tabular}{cc}
\multicolumn{2}{c}{$78 \cdot 02 \pm 2 \cdot 65$} \\
$\leqslant 3 \cdot 0$ & $>3 \cdot 0$ \\
6 & 8
\end{tabular}

$\begin{array}{cc}2 \cdot 2 \pm 0 \cdot 3 & 2 \cdot 4 \pm 0 \cdot 3 \\ 74 \pm 5^{\mathrm{c}} & 80 \pm 4^{\mathrm{c}} \\ 0 \cdot 8 \pm 0 \cdot 1^{*} & 1 \cdot 2 \pm 0 \cdot 1 \\ 0 \cdot 6 \pm 0 \cdot 1 & 0 \cdot 7 \pm 0 \cdot 1^{\mathrm{B}} \\ -0 \cdot 2 \pm 0 \cdot 1^{\mathrm{b} *} & -0 \cdot 5 \pm 0 \cdot 1^{\mathrm{B}+} \\ 1 \cdot 6 \pm 0 \cdot 1 & 1 \cdot 5 \pm 0 \cdot 4 \\ 4 \cdot 2 \pm 0 \cdot 0 & 4 \cdot 1 \pm 0 \cdot 5 \\ 2 \cdot 5 \pm 0 \cdot 3^{\mathrm{b}} & 1 \cdot 7 \pm 0 \cdot 4^{\mathrm{B}} \\ 0 \cdot 1 \pm 0 \cdot 1^{\mathrm{B} *} & 0 \cdot 4 \pm 0 \cdot 1^{\mathrm{B}+} \\ -1 \cdot 7 \pm 0 \cdot 3^{\mathrm{b}+} & -2 \cdot 4 \pm 0 \cdot 4^{\mathrm{B}+}\end{array}$

$\dagger$ Characteristics are defined in Table 1.

* Means of milk flow classes were significantly different within interruption class : $P<0.05$.

A, B,C Means of interruption classes (milk flow $>3.0 \mathrm{~kg} / \mathrm{min}$ ) without common subscript letters were significantly different: $P<0.05$.

a.b.c Means of interruption classes (milk flow $\leqslant 3.0 \mathrm{~kg} / \mathrm{min}$ ) without common subscript letters were significantly different: $P<0.05$.

+ Values of $\triangle \mathrm{PFR}(1 / 4), \triangle \mathrm{IP}$ and IP-EP were significantly different from zero: $P<0 \cdot 05$.

controls. The repeatabilities of the three quarter and left front quarter milk yields $(\mathrm{M}(3 / 4)$ and $\mathrm{M}(1 / 4))$, were 0.96 and 0.78 respectively.

Except for the high milk flow group, and then only if the interruption was at $75 \%$ of total milk yield, there was no significant difference between the PFR before and after interruption of milking and also no difference between the different interruption classes (PFR1(1/4) and PFR2(1/4); Table 2, Fig. 1). The repeatability for the three quarter PFR (PFR(3/4)) and PFR1(1/4) was 0.83.

Intramammary pressure. The time from the start of manual teat stimulation until maximal pressure (ejection pressure) was reached was $1.55 \pm 0.06 \mathrm{~min}$ (Fig. 1).

The mean baseline pressure and the mean ejection pressure were $1 \cdot 6 \pm 0 \cdot 1$ and $4 \cdot 2 \pm 0 \cdot 2 \mathrm{kPa}$ respectively. In both cases, there were no significant differences between the three interrupted milkings and control, and their repeatabilities were 0.58 and 0.89 respectively. During control milkings ejection pressure decreased to $3.8 \pm 0.2 \mathrm{kPa}$, but this change was not significant. The correlation between baseline pressure and the left quarter milk yield $(\mathrm{M}(1 / 4))$ was $0 \cdot 55$.

The interruption pressure decreased from the $25 \%$ to the $75 \%$ interruption, i.e. the decremental change (ejection pressure - interruption pressure) increased (Table 2 , Fig. 1). The correlation between interruption pressure and left front quarter milk yield after milking (M2(1/4), kg) was 0.76 . The IMP did not change during interruption ( $\triangle \mathrm{IP}$; Table 2 , Fig. 1) at 25 and $50 \%$ of total milk yield, but increased if milking was interrupted at $75 \%$ of total yield; however, this was significant only in the high milk flow group. 

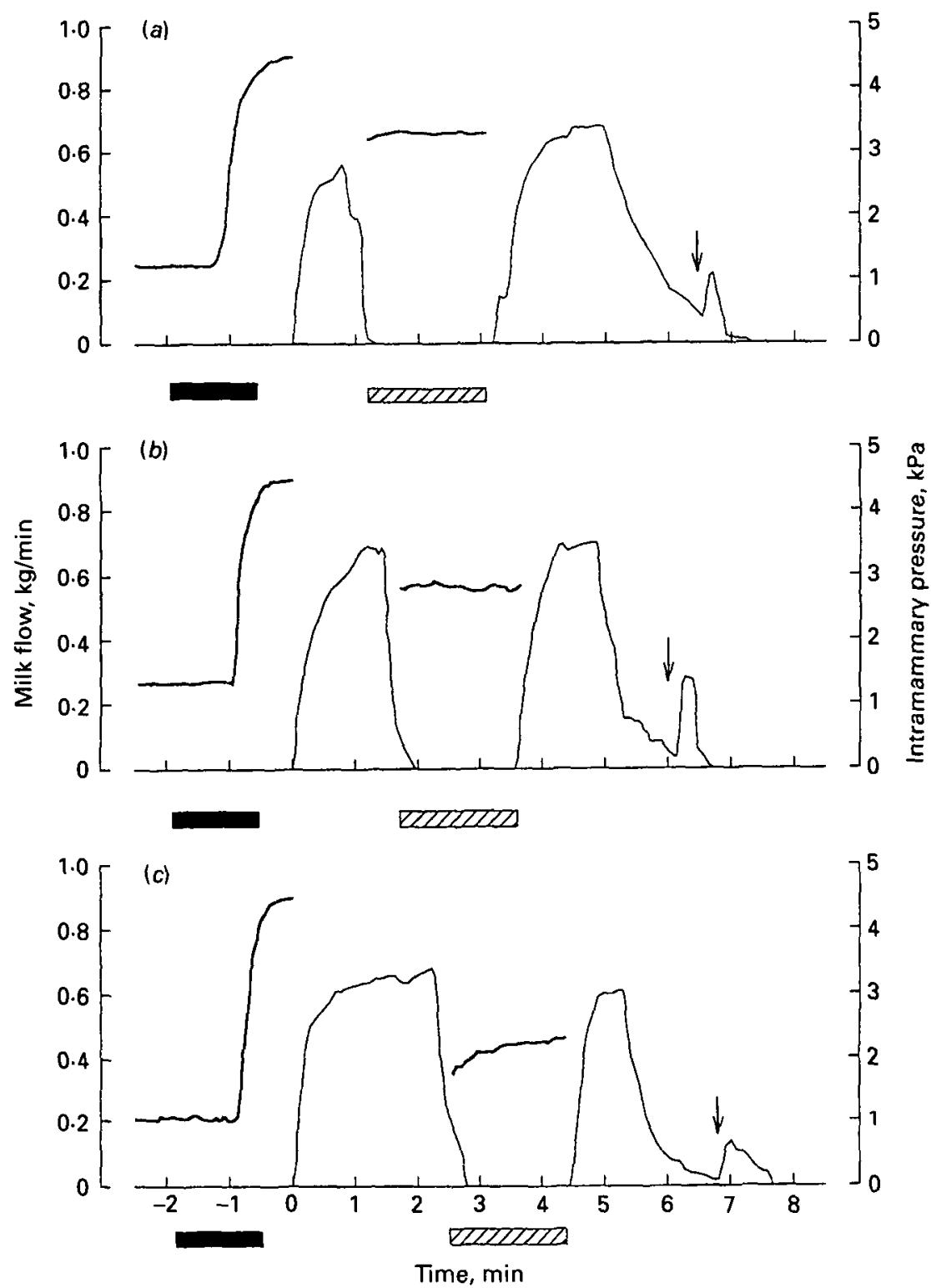

Fig. 1. - Mlilk flow and —-, intramammary pressure of the left front quarter of an individual cow before, during and after interruption of milking after removal of $(a) 25 \%,(b) 50 \%$ and $(c) 75 \%$ of the total milk yield. 0, Commencement of milking; $\mathbf{\square}$, teat stimulation; $\square$, intramammary pressure measurement in the left front quarter during interruption of milking; $\downarrow$, start of stripping.

\section{Experiment 2}

Milking time was significantly longer and PFR significantly lower if cows were milked at 50:50 than at 70:30 pulsation ratio (Table 3). Total and main milk yields and main flow rate were not significantly different between the two different pulsation ratios (Table 3 ). In Fig. 2 the two milk flow curves of one cow are shown as an example. 
Table 3. Milking characteristics with pulsation ratios of 50:50 and $70: 30$ (evening milking)

(Values are means $\pm \mathrm{se}$ for $n=19$ )

\begin{tabular}{lcc} 
& \multicolumn{2}{c}{ Pulsation ratio } \\
\cline { 2 - 3 } Variable & $50: 50$ & $70: 30$ \\
Total milk yield, kg & $12 \cdot 4 \pm 0 \cdot 7$ & $11 \cdot 8 \pm 0 \cdot 7$ \\
Main milk yield, kg & $12 \cdot 0 \pm 0 \cdot 7$ & $11 \cdot 4 \pm 0 \cdot 7$ \\
Stripping yield, kg & $0 \cdot 4 \pm 0 \cdot 1$ & $0 \cdot 4 \pm 0 \cdot 1$ \\
Main milking time, min & $6 \cdot 4 \pm 0 \cdot 3^{*}$ & $5 \cdot 4 \pm 0 \cdot 2^{*}$ \\
Peak flow rate, $\mathrm{kg} / \mathrm{min}$ & $3 \cdot 0 \pm 0 \cdot 2^{*}$ & $3 \cdot 8 \pm 0 \cdot 3^{*}$ \\
Mean flow rate, $\mathrm{kg} / \mathrm{min}$ & $1 \cdot 9 \pm 0 \cdot 1$ & $2 \cdot 1 \pm 0 \cdot 1$
\end{tabular}

* Means for different pulsation ratios were significantly different : $P<0-05$.

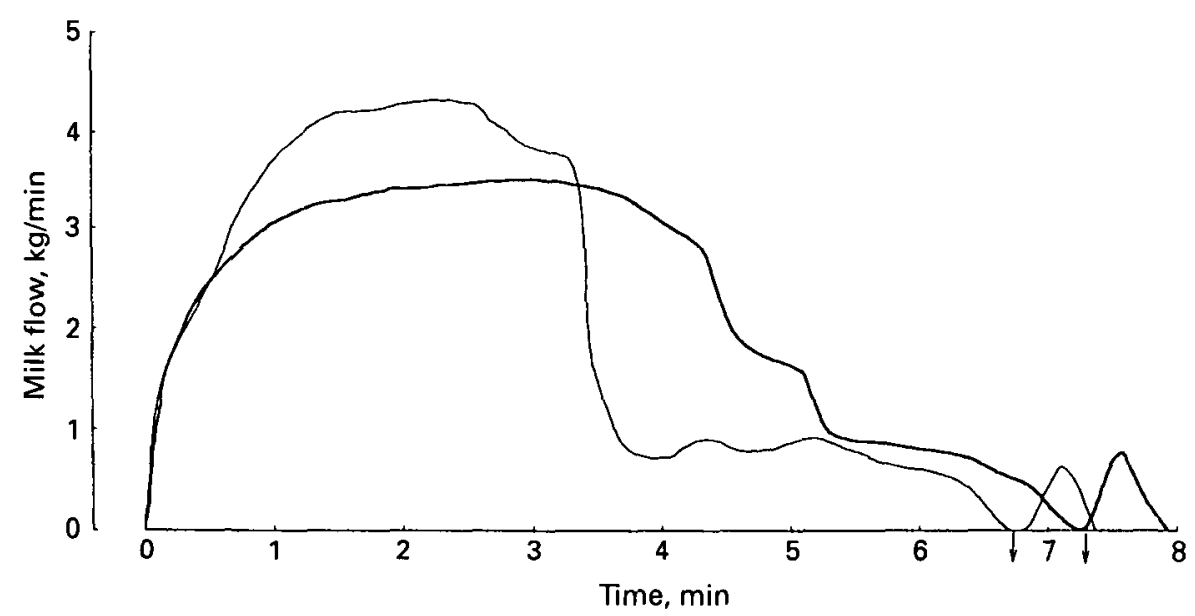

Fig. 2. Milk flow at a pulsation ratio of $-, 50: 50$ and $-, 70: 30$ for an individual cow. 0 , Commencement of milking; $\downarrow$, start of stripping.

\section{DISCUSSION}

Repeatabilities of milk yield and PFR were very high, so the interruption of milking did not influence these traits.

The levels of baseline and ejection IMP in this study were similar to those previously measured (Mayer et al. 1991). During control milking the ejection pressure decreased slightly in the unmilked quarter during milking of the other quarters. It can be assumed that elevated oxytocin concentrations and myoepithelial contractions were maintained during the entire milking (Mayer et al. 1984 ; Bruckmaier et al. 1994). Therefore, the IMP should have been constant at its maximum level. The slight decrease in IMP was possibly due to evacuation and tissue relaxation of the other quarters and agrees with earlier findings (Whittlestone, 1955). There was some correlation between baseline pressure and the corresponding quarter milk yield. It is likely that the baseline pressure is generated mainly by the hydrostatic pressure of the cisternal milk. However, its repeatability was not very high, so there was presumably a considerable day-to-day variation in the amount of cisternal milk, whereas the milk yield was shown to be highly repeatable. Milk shifted from the alveolar compartment into the cistern in the absence of milk ejection was shown to 
increase with increasing time from the previous milking (Knight et al. 1994). Simultaneously, IMP in the cistern increases continuously (Bruckmaier, 1988).

The repeatability of ejection pressure was high and it was shown in earlier investigations that oxytocin release, which is caused by teat stimulation, forces alveolar milk into the cisternal cavity until the pressure increase within the teat cistern reaches' a physiologically, anatomically and individually determined maximum (Mayer et al. 1991; Bruckmaier et al. 1991, 1994; Bruckmaier \& Blum, 1992).

However, the ejection pressure was not correlated with milk flow rates. Furthermore, the milk flow was not influenced by the decrease in IMP (the difference between the interruption and ejection pressures), that is the PFR returned to the same level after as before milking interruption, except for the high milk flow group and only then if there was only a very small amount of milk left in the udder $(75 \%$ interruption). Since the negative pressure of the milking vacuum is about 10 -fold that of the IMP, it is likely that changes in IMP have no great influence on milk flow. Earlier investigations have shown that PFR is correlated with the extendibility of the teat canal (Andreae, 1958) and the muscle tone around the teat sphincter (Williams \& Mein, 1987) and the mammary ducts, which are controlled by the adrenergic system (Roets et al. 1984; Roets \& Peeters, 1985; Butler et al. 1992; Hammon et al. 1994). However, these investigations do not explain why the milk flow rate is decreasing towards the end of the milking.

No increase in IMP was observed when milking was interrupted at 25 and $50 \%$ of expected total yield, so obviously the milk ejection rate was sufficiently high to keep the mammary cistern filled.

However, a decreasing ejection rate is likely to occur, particularly toward the end of milking. The surface of the milk droplets in the alveoli is decreasing during milking, hence stronger contraction of the myoepithelial cells is needed for a constant milk ejection rate. It has been shown that the time from the start of stimulation and also the time from the start of IMP increase until maximal IMP is reached are dramatically prolonged if milk yield drops below $5 \mathrm{~kg}$ in late lactation (Bruckmaier, 1988; Bruckmaier et al. 1992). In cows with central inhibition of milk removal the time from oxytocin injection to commencement of milk flow was inversely correlated with the amount of milk actually removed in response to the injection of oxytocin (Bruckmaier et al. 1994). At the end of milking (interruption of milking at $75 \%$ of expected total yield) there was more milk removed by the milking machine than could be transported to the cisternal cavity. During interruption of milking the cistern was in part refilled, as indicated by an increase in IMP. This phenomenon was probably due to a delay in milk ejection rate as compared with milk flow, i.e. the milk removal rate towards the end of milking. As expected, this delay was especially pronounced in cows with a high milk flow.

By reduction of the pulsation ratio (from 70:30 to 50:50), the PFR was reduced and the duration of high milk flow prolonged while the main flow rate was not significantly altered. Obviously, the PFR could be adapted to the (alveolar) milk ejection rate for a prolonged period. This is in agreement with Thomas et al. (1991), who changed the pulsation ratio from 50:50 to 70:30. In their experiment the average flow rate increased slightly, while the 2 min milk yields increased by $23 \%$. Mihina et al. (1990) developed equipment that could control the pulse frequency of milking machines in response to the ejection rate and, by using this, average milk flow was increased while maximum milk flow rate was slightly decreased.

In conclusion, reduced milk ejection rate has been demonstrated during late 
milking. Continuous adjustment of the milking machine characteristics such as pulsation ratio to the current milk ejection rate during the course of milking should theoretically equilibrate milk flow rate.

This study was supported by Alfa Laval Agri, Sursee (Switzerland) and Tumba (Sweden).

\section{REFERENCES}

ANDREAE, U. 1958 [Measurements of the teat canal of cows to determine the ease of milking.] Zeitschrift für Tierzüchtung und Züchtungsbiologie $71289-298$

Bruckmai er, R. M. 1988 [Oxytocin Release, Intramammary Pressure and Milk Production in the Cow in Relation to Stage of Lactation and Effect of the Adrenergic System.] Thesis, Technische Universität Minchen, Weihenstephan, Germany

BruckMAIER, R. M. \& BLUM, J. W. 1992 B-mode ultrasonography of mammary glands of cows, goats and sheep during $\alpha$-and $\beta$-adrenergic agonist and oxytocin administration. Journal of Dairy Research $59151-159$

Bruckmaler, R. M., MaYer, H. \& Schams, D. 1991 Effects of $\alpha$-and $\beta$-adrenergic agonists on intramammary pressure and milk flow in dairy cows. Journal of Dairy Research 58 411-419

Bruckmaier, R. M., Schams, D. \& Blum, J. W. 1994 Continuously elevated concentrations of oxytocin during milking are necessary for complete milk removal in dairy cows. Journal of Dairy Research $61323-334$

Bruckmalek, R. M., Schams, D. \& M MYer, H. 1992 [Stimulation, free oxytocin, intramammary pressure and milk flow in cattle: dependence on stage of lactation.] In Beiträge zum internationalen Kolloquium "Stimulation und Melken", Grimma, Germany

Butlek, M. C., Hillerton, J. E. \& Grindal, R. J. 1992 The control of milk flow through the teats of dairy cows. Journal of Dairy Science 75 1019-1024

EssL, A. 1987 Statistische Methoden in der Tierproduktion. Vienna: Österreichisch Agrarverlag

Gorewit, R. C. 1979 Method for determining oxytocin concentrations in unextracted sera: characterization in lactating cattle. Proceedings of the Society for Experimental Biology and Nedicine 160 $80-87$

Hammon, H. M., Bruckmaier, R. M., Honegger, U. E. \& Blum, J. W. 1994 Distribution and density of $\alpha$ - and $\beta$-adrenergic receptor binding sites in the bovine mammary gland. Journal of Dairy Research $6147-57$

Knigh', C. H., HiRs', D. \& Dewhurst, R. J. 1994 Milk accumulation and distribution in the bovine udder during the interval between milkings. Journal of Dairy Research 61 167-177

MAYER, H., BRUCKMAIER, R. M. \& SCHaMS, D. 1991 Lactational changes in oxytocin release, intramammary pressure and milking characteristics in dairy cows. Journal of Dairy Research 58 159-169

Mayer, H., Schams, D., Worstorff, H. \& Prokopp, A. 1984 Secretion of oxytocin and milk removal as affected by milking cows with and without manual stimulation. Journal of Endocrinology 103 355-361

Mlhina, Š., Janci, P., Tongel', P. \& Novosedíková, I. 1990 [Control of milking machine pulsation.] Zemedelska Technika 36 475-481

Roets, E. \& Peeters, G. 1985 Identification and characterization of ${ }^{3} \mathrm{H}$-prazosin binding to $\alpha_{1}$-adrenoceptors in bovine teat muscles. Archives Internationales de Pharmacodynamie et de Thérapie $275189-198$

Roets, E., Penters, G. \& Leysen, J. E. 1984 Identification of $\beta$-adrenoceptors in bovine teat muscles by ${ }^{3} \mathrm{H}$ dihydroalprenolol binding. Archives Internationales de Pharmacodynamie et de Thérapie $270203-214$

SAS 1990 SAS Users' Guide: Statistics. Cary, NC: SAS Institute

Schams, D., Mayer, H., Prokopp, A.\& Worstorff, H. 1984 Oxytocin secretion during milking in dairy cows with regard to the variation and importance of a threshold level for milk removal. Journal of Endocrinology $102337-343$

Thomas, C. V., Force, D. K., Bremel, D. H. \& Strasser, S. 1991 Effects of pulsation ratio, pulsation rate, and teatcup liner design on milking rate and milk production. Journal of Dairy Science 74 1243-1249

Whitrles'rone, W. G. 1955 Intramammary pressure changes in the lactating cow. I. Changes during the milking process. Journal of Dairy Research 22 290-294

Willians, D. M. \& Mein, G. A. 1987 Closing forces of the bovine teat canal. Journal of Dairy Research 54 $321-325$ 